\title{
TITLE:
}

\section{$<$ News> Bush Fire Control Using Arbors in Green Corridor Project at Bossou}

\section{AUTHOR(S):}

Morimura, Naruki; Ohashi, Gaku; Soumah, Gaspard; Matsuzawa, Tetsuro

\section{CITATION:}

Morimura, Naruki ...[et al]. <News> Bush Fire Control Using Arbors in Green Corridor Project at Bossou. Pan Africa News 2011, 18(1): 10-12

ISSUE DATE:

2011-06

URL:

http://hdl.handle.net/2433/143526

RIGHT:

Copyright (C) Pan Africa News. 


\title{
<NEWS> \\ Bush Fire Control Using Arbors in Green Corridor Project at Bossou
}

\author{
Naruki Morimura ${ }^{1}$ Gaku Ohashi², \\ Aly Gaspard Soumah ${ }^{3} \&$ Tetsuro \\ Matsuzawa ${ }^{4}$ \\ 1 Wildlife Research Center, Kyoto University, Japan \\ 2 Japan Monkey Centre, Japan \\ 3 Institut de Recherche Environnementale de Bossou. \\ Guinea \\ 4 Primate Research Institute, Kyoto University, Japan \\ (E-mail: nmorimura@wrc.kyoto-u.ac.jp)
}

A group of chimpanzees live near Bossou in Guinea, West Africa. Bossou is a village located west of the Nimba Mountains, the only World Natural Heritage site (UNESCO/MAB) in Guinea. Bossou chimpanzees are well known to use a variety of different tools that have been studied in details over the past 35 years $^{1}$. The number of chimpanzees in Bossou community are stable, counting 19 individuals on average (range: 16-22) from 1976 to 2003, but we have lost five chimpanzees due to flu-like epidemic in November $2003^{2,3}$. The number of Bossou chimpanzees are now 12, stabilized over the past three years. No female chimpanzees immigrated since the beginning of field study. The Green Corridor Project ${ }^{4}$, a tree plantation effort has begun in 1997 as a $4 \mathrm{~km}$ long expanse across the savanna area separating Bossou from Nimba Mountains ${ }^{5,6}$. The project is expected to promote individual interchange between the Bossou and Nimba groups as part of the conservation effort of wild chimpanzees.

Since our initial efforts 8 years ago, some forest tree species, such as Uapaca heudelotii, have survived well when planted in the savanna ${ }^{7}$. We have also piloted a work of sapling nursery using chimpanzees' feces. Saplings grown from feces secreted by chimpanzees, commonly known as seed dispersal, were planted in savanna. Naturally, the germinating rate of seeds increases, when seeds pass through the intestine of a chimpanzee. We applied seed dispersion in natural ecosystem into a plantation. We have taken care of saplings in a tree nursery with sufficient humidity and filtered sunlight. After the saplings grown up to over $50 \mathrm{~cm}$ high, we have transported them into the savanna. Unfortunately, the saplings were exposed to strong sunshine in the savanna, and then some of them died within a few days. To protect the fragile saplings, we have planted them in manioc field or covered 


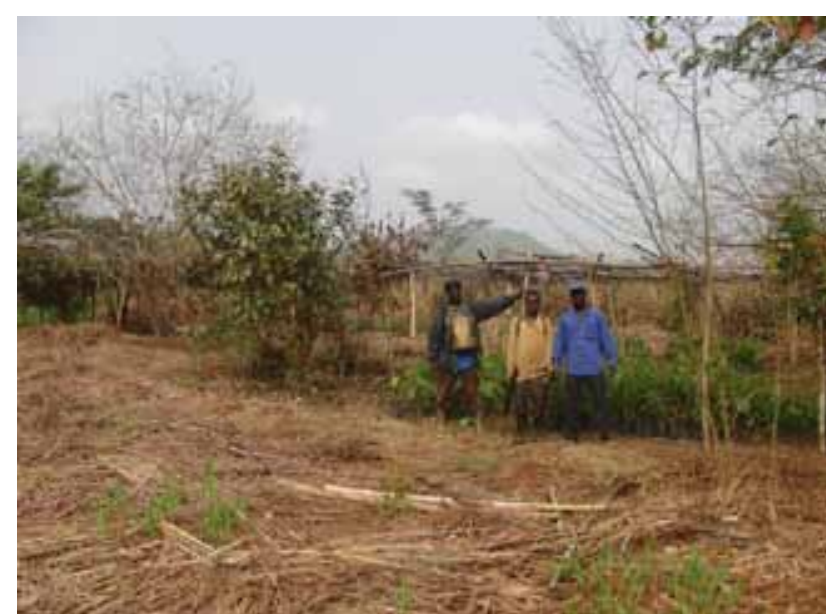

Figure 1. Local workers in Bossou take care of arbors in the corridor.

the saplings by HEXATUBE (Phytoculture Control corp.) to reach better success rate. With this effort, we managed to protect saplings from drought and strong sunshine in savanna.

We found that young trees should be grown under similar condition as the nursery condition after transportation to the savanna. We have set out arbors to cover saplings to minimize damage caused by solar insolation in the savanna. The arbors that are about $1.8 \mathrm{~m}$ in height were constructed from natural materials such as bamboos as columns, leaf stalks of Raffia as beams, and palm leaves as roof. The arbors provide shadow over the sapling during strong sunshine, while the arbors mold gradually as days go by. We began this new protocol employing three arbors and transplanted 25 Uapaca heudelotti saplings under each of them (i.e., 75 saplings in total) in $2007^{\circ}$. We have constructed 23 arbors until September 2008.

Moreover, we set a 10-m-wide and 4-km-long firebreak gap area by removing dry vegetation as a corridor system, because the arbors are highly susceptible to bush fire, especially in dry season. Local people at Bossou and Seringbara patrolled and took care of the corridor area (Figure 1). However, bush fire occurred outside of the corridor expended and burned 11 out of 23 arbors on January 20 th, 2009. Fortunately we have managed to recover up to 27 arbors in the corridor, after the bushfire. We also cut the grass intensively in the area of 3 to $5 \mathrm{~m}$ around arbors and at maintenance pass in dry season, from January until March 2011.

On February 7th, 2011, bush fire entered into the corridor again by skipping a $10-\mathrm{m}$-wide firebreak due to strong wind (Figure 2). A post-survey estimated that the fire burned about one-third of the corridor area. At the same time, the survey found that the arbors in the corridor had no damage at all from the fire. The bush fire surrounded eight arbors at least, and then stopped besides them. The reason is that the grass was cut in the corridor. We had also taken away all dried grass and dead woods around arbors before the bush fire occurred. Even if fire intensified when windy, the wind passed over a few lying dry materials on the ground around arbors, preventing blaze. As the result showed, the fire got weak and stopped

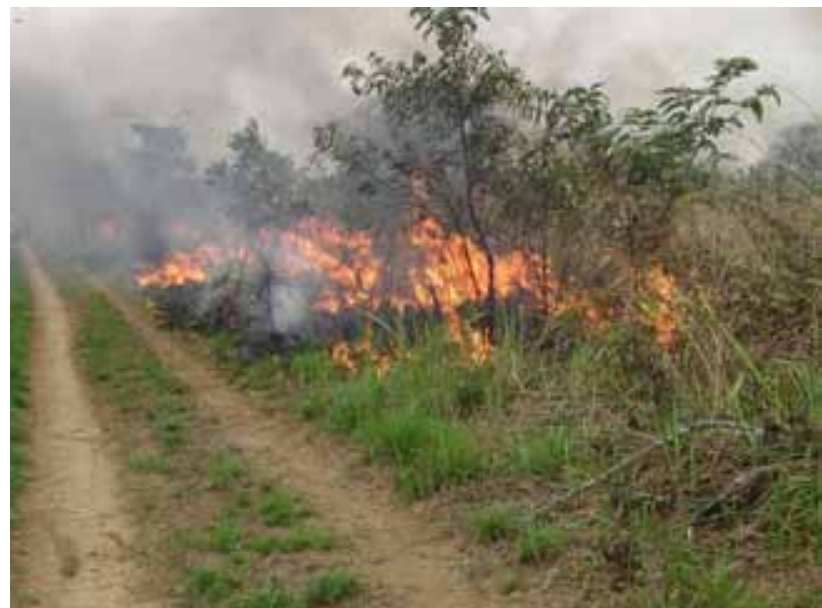

Figure 2. Bush fire expanded again into the corridor area on February 7th, 2011.

in front of the arbors. Green patches of young trees at arbors looked like islands on burnt remains of savanna (Figure 3).

Our experience proved that the arbors with sufficient care played a similar role as the firebreak. The bush fire stopped at the line of the arbors and passed over them. While a $10-\mathrm{m}$-wide firebreak is effective to prevent direct expansion of bush fire to reach the corridor, it is also difficult to sweep dry material through long distances in order to keep the firebreak clean from debris. It is not very realistic to prevent getting the bush fire into the corridor completely, but it should be controlled to minimize damage to young trees and arbors. Daily care of cutting the grass is necessary to keep the lookout on all the areas surrounding arbors and/or planted trees sufficiently. The more we construct and take care of the arbors with sufficient care, such as cutting the grass, the corridor area will have more resistance to the bush fire.

Saplings can grow up in savanna. Some of young trees became over $4 \mathrm{~m}$ high after removing arbors. Once the roots of the saplings deeply inside the ground, they grow up to be a young tree, an arbor is no longer necessary for the tree to survive under such severe conditions in the savanna. Grown trees shadow other saplings beneath them, which takes more time to grow under the

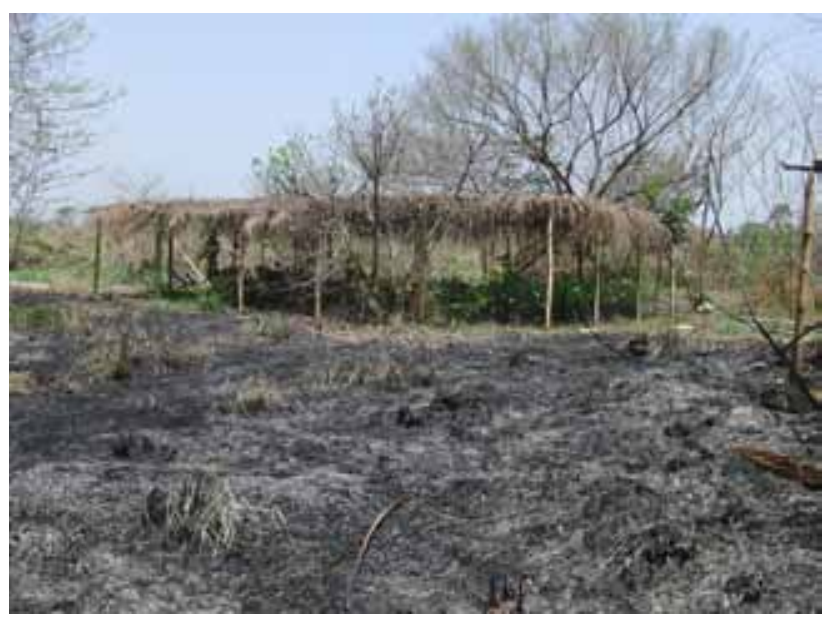

Figure 3. The post-survey found that the bush fire stopped at a line of arbors and at its maintenance pass with sufficient care of cutting the grass. 
filtered sunlight. When the height of young trees reaches the roof of the arbors, we take away all molded remains of columns, beams, and roof. Those natural materials are possibly sustainable resources in a course of natural ecosystem. In 2011, we have a plan to plant 20,000 saplings in to the corridors with the support by Toyota Foundation. Green Corridor Project has entered into a new phase by introducing the arbors procedure in larger scale of our tree plantation.

\section{ACKNOWLEDGMENTS}

This work was financially supported by MEXT-20002001 to TM. The current project is also funded by the HOPE project (21-010, AS-22-023) of Primate Research Institute of Kyoto University to NM, the Toyota Environmental Activities Grant Program (G2010-009) of Toyota Motor Corporation to TM, and the Environment Research and Technology Development Fund (D-1007) of the Ministry of the Environment, Japan to TM. Thanks are also due to the Guinean authorities, Dr. Gnan Clotaire Maomy from the DNRST. We thank the contributions for promoting this project such as Bouna Zogbila, Remy Touré, and Diri Bamba. We are also grateful for the effort of colleagues who contributed this project during various stages; Drs. Yukimaru Sugiyama, Gen Yamakoshi, Tatyana Humle, and Nicolas Granier. Thanks are given to Mr. Michael Seres for insightful comments related to an earlier version of the manuscript.

\section{REFERENCES}

1. Matsuzawa T, Humle T, Sugiyama Y 2011. The Chimpanzees of Bossou and Nimba. Springer, Tokyo.

2. Biro D, Humle T, Koops K, Sousa C, Hayashi M, Matsuzawa T 2010. Chimpanzee mothers at Bossou, Guinea carry the mummified remains of their dead infants. Curr Biol 20:R351-R352.

3. Humle T 2011. The 2003 epidemic of a flu-like respiratory disease at Bossou. In: The Chimpanzees of Bossou and Nimba. Matsuzawa T, Humle T, Sugiyama Y (eds) Springer, Tokyo, pp. 325-334.

4. Matsuzawa T, Kourouma M 2008. The Green Corridor Project: long-term research and conservation in Bossou, Guinea. In: Science and Conservation in African Forests: the Benefits of Long-Term Research. Wrangham R, Ross E (eds), Cambridge Univ Press, New York, pp. 201-212.

5. Matsuzawa T, Ohashi G, Humle T, Granier N, Kourouma M, Soumah AG 2011. Green Corridor Project: planting trees in the savanna between Bossou and Nimba. In: The Chimpanzees of Bossou and Nimba. Matsuzawa T, Humle T, Sugiyama Y (eds), Springer, Tokyo, pp. 361-370.

6. Hirata S, Morimura N, Matsuzawa T 1998. Green passage plan (tree-planting project) and environmental education using documentary videos at Bossou: a progress report. Pan Afr News 5:18-20.

7. Matsuzawa T 2007. Assessment of the planted trees in Green Corridor Project. Pan Afr News 14:27-29.

8. Ohashi G, Hasegawa R, Kourouma M, Matsuzawa T 2008. Arbors and cuttings: new trials for green corridor project at Bossou-Nimba. Pan Afr News 15:20-23. 